\title{
Estimating healthcare costs of acute gastroenteritis and human campylobacteriosis in Switzerland
}

\author{
C. SCHMUTZ ${ }^{1,2}$, D. MÄUSEZAHL ${ }^{1,2} *$, P. J. BLESS ${ }^{1,2}$, C. HATZ ${ }^{1,2,3}$, \\ M. SCHWENKGLENKS ${ }^{2,3,4}$ AND D. URBINELLO ${ }^{1,2}$ \\ ${ }^{1}$ Swiss Tropical and Public Health Institute, Basel, Switzerland \\ ${ }^{2}$ University of Basel, Basel, Switzerland \\ ${ }^{3}$ Epidemiology, Biostatistics and Prevention Institute, University of Zurich, Zurich, Switzerland \\ ${ }^{4}$ Institute of Pharmaceutical Medicine, University of Basel, Basel, Switzerland
}

Received 2 December 2015; Final revision 19 June 2016; Accepted 3 July 2016;

first published online 12 August 2016

\section{SUMMARY}

Rising numbers of campylobacteriosis case notifications in Switzerland resulted in an increased attention to acute gastroenteritis (AG) in general. Patients with a laboratory-confirmed Campylobacter infection perceive their disease as severe and around $15 \%$ of these patients are hospitalized. This study aimed at estimating healthcare costs due to AG and campylobacteriosis in Switzerland. We used official health statistics, data from different studies and expert opinion for estimating individual treatment costs for patients with different illness severity and for extrapolating overall costs due to AG and campylobacteriosis. We estimated that total Swiss healthcare costs resulting from these diseases amount to €29-45 million annually. Data suggest that patients with AG consulting a physician without a stool diagnostic test account for €9.0-24.2 million, patients with a negative stool test result for Campylobacter spp. for $€ 12.3$ million, patients testing positive for Campylobacter spp. for $€ 1.8$ million and hospitalized campylobacteriosis patients for $€ 6.5$ million/year. Healthcare costs of campylobacteriosis are high and most likely increasing in Switzerland considering that campylobacteriosis case notifications steadily increased in the past decade. Costs and potential cost savings for the healthcare system should be considered when designing sectorial and cross-sectorial interventions to reduce the burden of human campylobacteriosis in Switzerland.

Key words: Acute gastroenteritis, campylobacteriosis, healthcare costs, Switzerland.

\section{INTRODUCTION}

Since 1995 Campylobacter spp. has been the most frequently reported gastrointestinal bacterial pathogen in humans in Switzerland [1] and since 2005 in the European Union (EU) [2]. An estimated $9 \cdot 25$ million cases of campylobacteriosis occurred in 2009 in the

\footnotetext{
* Author for correspondence: D. Mäusezahl, Swiss Tropical and Public Health Institute, Socinstrasse 57, P.O. Box, CH-4002 Basel, Switzerland.

(Email: daniel.maeusezahl@unibas.ch)
}

27 EU member states, of which around 2\% were reported [3]. Havelaar et al. estimated the 'true' incidence rate of campylobacteriosis in these countries at $30-13500 / 100000$ population $(350 / 100000$ in Switzerland).

In Switzerland, positive test results for Campylobacter spp. have to be notified by diagnostic laboratories to the Federal Office of Public Health (FOPH) since 1988 [4]. In 2012, 8480 campylobacteriosis cases were registered within the National Notification System for Infectious Diseases (NNSID), which is the highest number

This is an Open Access article, distributed under the terms of the Creative Commons Attribution licence (http://creativecommons.org/licenses/by/4.0/), which permits unrestricted re-use, distribution, and reproduction in any medium, provided the original work is properly cited. 
reported so far [1]. This corresponds to a notification rate of 105 cases $/ 100000$ resident population in Switzerland. The extent to which campylobacteriosis contributes to the public health burden of acute gastrointestinal illness is unknown. In The Netherlands, about twice the population size of Switzerland, approximately 4.8 million cases of gastroenteritis occur annually, whereby 220000 patients need medical consultation [5].

A study among 69 general practitioners (GPs) concluded a rising awareness of campylobacteriosis as a public health problem in Switzerland (Supplementary material). Despite its mostly self-limiting nature, the health burden of campylobacteriosis in the Swiss population may be significantly higher than figures from the NNSID indicate. Severe cases and complications such as Guillain-Barré syndrome, reactive arthritis and post-infectious irritable bowel syndrome amplify the burden of disease and in particular the economic burden [6-8].

The estimated economic burden (equating healthcare costs at large, including, e.g. loss of productivity and/or transportation and other direct and indirect non-healthcare costs) of gastrointestinal infections or foodborne illnesses in high-income countries varies between $€ 14$ (Australia [9]) and $€ 1305$ (United States [10]) per case in the community ([9-20] in Table 1). Thereby, healthcare costs account for $€ 3-155 /$ case in the community [9-20]. This wide range is partially due to heterogeneity in case definitions and definitions of economic burden. The yearly costs for gastroenteritis due to 14 food-related pathogens and associated sequelae in The Netherlands were estimated at around $€ 468$ million [11].

For campylobacteriosis, the estimated economic burden per case varies, ranging from $€ 117$ (The Netherlands [17]) to $€ 6141$ (United States [12]) ([8, 10-12, 17, 20, 26] in Table 2). Healthcare costs of campylobacteriosis cases were estimated at $€ 8 /$ case in New Zealand, €82-280 in The Netherlands and $€ 163-253$ in the United States $([8,10-12,20]$ in Table 2). These numbers are difficult to compare as case definitions and cost items included vary between studies. For example, sequelae due to campylobacteriosis were considered in some studies while in others they were not. Campylobacteriosis-associated acute gastroenteritis (AG) accounts for approximately 108000 cases/year in The Netherlands, causing annual societal costs of about $€ 81.5$ million (including sequelae) [11]. In the EU, campylobacteriosis cases account for expenditures of public health systems and for productivity losses of around $€ 2.4$ billion/year according to the European Food Safety Authority [28]. The economic burden highlights the importance of this widespread and common disease.

A quantification of healthcare costs due to AG and/ or campylobacteriosis in Switzerland is lacking so far. Due to the rising number of campylobacteriosis case notifications in recent years, we conducted several studies which aimed at generating a better understanding of the epidemiology of campylobacteriosis in Switzerland. We investigated epidemiological determinants [29], described time trends in notification data [1], the campylobacteriosis-associated illness experience from the patients' perspective [29, 30], the case management strategies of GPs (Supplementary material) and laboratory positivity rates of Campylobacter spp. (Supplementary material). In concert, these studies indicate that campylobacteriosis is causing a considerable burden of disease which considerably impacts the health system in Switzerland and is likely associated with high costs.

The aim of this study was to estimate the total annual costs for the medical treatment of campylobacteriosis in Switzerland. However, given that available data do not systematically distinguish campylobacteriosis from $\mathrm{AG}$ we focused this analysis on available data of both conditions. To the best of our knowledge, this is the first study estimating healthcare costs due to AG and campylobacteriosis in Switzerland.

\section{METHODS}

We developed patient management models and estimated their frequency and associated costs from the perspective of the healthcare system.

\section{Typology of patients: patient management models}

Cost estimation was based on four different patient management models for $\mathrm{AG}$ which were derived from a broad expert consultation across a purposive enquiry among practitioners in private general and specialized practices (four), clinics and university hospitals (four), authors opinions and data available to them: (i) patients consulting a physician without stool testing (patient management model A), (ii) patients consulting a physician with negative Campylobacter stool test results (patient management model B), (iii) patients consulting a physician and having a positive Campylobacter stool test result (patient management model C), and (iv) hospitalized campylobacteriosis cases (patient management model D). 
Table 1. Overview of selected studies estimating the cost of illness of gastrointestinal or foodborne illnesses

\begin{tabular}{|c|c|c|c|c|c|c|c|c|c|c|c|c|c|}
\hline \multirow[b]{2}{*}{$\begin{array}{l}\text { First } \\
\text { author, year } \\
\text { [ref.] }\end{array}$} & \multirow[b]{2}{*}{ Nation } & \multirow[b]{2}{*}{ Year } & \multirow[b]{2}{*}{$\begin{array}{l}\text { Pathogens/disease } \\
\text { considered } \\
\text { (community cases, } \\
\text { unless specified } \\
\text { otherwise) }\end{array}$} & \multirow[b]{2}{*}{$\begin{array}{l}\text { Cases per } \\
\text { year }\end{array}$} & \multicolumn{4}{|c|}{ Costs included ${ }^{\mathrm{a}}$} & \multirow[b]{2}{*}{$\begin{array}{l}\text { Exchange } \\
\text { rate used } \\
(€ 1=\ldots)^{\mathrm{c}}\end{array}$} & \multirow[b]{2}{*}{$\begin{array}{l}\text { Direct } \\
\text { healthcare } \\
\text { cost, per } \\
\text { case (in } € \text { ) }\end{array}$} & \multirow[b]{2}{*}{$\begin{array}{l}\text { Direct } \\
\text { healthcare } \\
\text { cost, yearly } \\
\text { (in million } € \text { ) }\end{array}$} & \multirow[b]{2}{*}{$\begin{array}{l}\text { Total costs } \\
\text { per case } \\
\text { (in } € \text { ) }\end{array}$} & \multirow[b]{2}{*}{$\begin{array}{l}\text { Total yearly } \\
\text { costs (in } \\
\text { million } € \text { ) }\end{array}$} \\
\hline & & & & & $\begin{array}{l}\text { Direct } \\
\text { healthcare } \\
\text { cost }\end{array}$ & $\begin{array}{l}\text { Patient } \\
\text { costs } \\
\text { (e.g. } \\
\text { travel } \\
\text { costs) }\end{array}$ & $\begin{array}{l}\text { Productivity } \\
\text { losses }\end{array}$ & Others ${ }^{\mathrm{b}}$ & & & & & \\
\hline $\begin{array}{l}\text { Hoffmann, } \\
2015 \text { [10] }\end{array}$ & United States & 2013 & $\begin{array}{l}15 \text { foodborne } \\
\text { pathogens } \\
\text { including } \\
\text { long-term } \\
\text { disabilities; only } \\
\text { domestically } \\
\text { acquired and } \\
\text { foodborne cases }\end{array}$ & 8914713 & $\mathrm{X}$ & & $\mathrm{x}$ & $\mathrm{X}$ & USD $1 \cdot 34$ & $155^{\mathrm{d}}$ & 1384 & $1305^{\mathrm{d}}$ & 11636 \\
\hline $\begin{array}{l}\text { Mangen, } \\
2015 \text { [11] }\end{array}$ & Netherlands & 2011 & $\begin{array}{l}14 \text { foodborne } \\
\text { pathogens; } \\
\text { including } \\
\text { sequelae }\end{array}$ & 4810000 & $\mathrm{X}$ & $\mathrm{X}$ & $\mathrm{X}$ & & EUR 1 & $31^{\mathrm{d}}$ & 147 & $97^{\mathrm{d}}$ & 468 \\
\hline $\begin{array}{l}\text { Scharff, } \\
2012 \text { [12] }\end{array}$ & United States & 2010 & $\begin{array}{l}\text { All domestically } \\
\text { acquired, } \\
\text { foodborne } \\
\text { illnesses }\end{array}$ & 47780778 & $\mathrm{X}$ & & $\mathrm{X}$ & $\mathrm{X}$ & USD 1.33 & 75 & $3568^{\mathrm{d}}$ & $806-1227$ & $\begin{array}{r}38506- \\
58589\end{array}$ \\
\hline $\begin{array}{l}\text { Friesema, } \\
2012 \text { [13] }\end{array}$ & Netherlands & 2009 & Gastroenteritis & 4600000 & $\mathrm{X}$ & $\mathrm{X}$ & $\mathrm{x}$ & & EUR 1 & $14^{\mathrm{d}}-32^{\mathrm{d}}$ & $63-147$ & 133-151 & $611-695$ \\
\hline $\begin{array}{l}\text { Gauci, } 2007 \\
\text { [14] }\end{array}$ & Malta & $2004 / 05$ & $\begin{array}{l}\text { Infectious } \\
\text { intestinal disease }\end{array}$ & 164471 & $\mathrm{X}$ & $\mathrm{X}$ & $\mathrm{x}$ & & $\operatorname{Lm} 0 \cdot 44^{\mathrm{e}}$ & $72^{\mathrm{d}}$ & 12 & 108 & 17 \\
\hline $\begin{array}{l}\text { Abelson, } \\
2006[15]\end{array}$ & Australia & 2004 & $\begin{array}{l}\text { Gastroenteritis } \\
\text { due to foodborne } \\
\text { illnesses }\end{array}$ & $5400000^{\mathrm{f}}$ & $\mathrm{X}$ & & $\mathrm{x}$ & $\mathrm{X}$ & AUD 1.69 & $22^{\mathrm{d}}$ & 118 & $111^{\mathrm{d}}$ & 598 \\
\hline $\begin{array}{r}\text { Majowicz, } \\
2006[16]\end{array}$ & $\begin{array}{l}\text { City of } \\
\text { Hamilton, } \\
\text { Canada }\end{array}$ & 2001 & $\begin{array}{l}\text { Acute } \\
\text { gastroenteritis }\end{array}$ & $619334^{\mathrm{g}}$ & $\mathrm{X}$ & & $\mathrm{X}$ & & CAD 1.39 & $17^{\mathrm{d}}$ & $11^{\mathrm{d}}$ & 66 & 40 \\
\hline $\begin{array}{l}\text { Van den } \\
\text { Brandhof, } \\
2004 \text { [17] }\end{array}$ & Netherlands & 1999 & Gastroenteritis & 4476399 & $\mathrm{X}$ & $\mathrm{X}$ & $\mathrm{X}$ & & EUR 1 & 14 & 61 & 77 & 345 \\
\hline $\begin{array}{l}\text { Roberts, } \\
2003 \text { [18] }\end{array}$ & England & 1994 & $\begin{array}{l}\text { Infectious } \\
\text { intestinal disease }\end{array}$ & $9400000^{\mathrm{h}}$ & $\mathrm{X}$ & $\mathrm{X}$ & $\mathrm{x}$ & & $\begin{array}{l}\text { GBP 0.66 } \\
\text { (year } \\
1999 \text { ) }\end{array}$ & $16^{\mathrm{d}}-44^{\mathrm{d}}$ & $153-412$ & $109^{\mathrm{d}}-120$ & $1028-1128$ \\
\hline $\begin{array}{l}\text { Hellard, } \\
2003[9]\end{array}$ & Australia & 1999 & $\begin{array}{c}\text { Highly credible } \\
\text { gastroenteritis }\end{array}$ & 15173430 & $\mathrm{X}$ & & $\mathrm{X}$ & & AUD 1.65 & $3^{\mathrm{d}}$ & 46 & $14^{\mathrm{d}}$ & 208 \\
\hline
\end{tabular}




\begin{tabular}{|c|c|c|c|c|c|c|c|c|c|c|c|c|c|}
\hline \multirow[b]{2}{*}{$\begin{array}{l}\text { First } \\
\text { author, year } \\
\text { [ref.] }\end{array}$} & \multirow[b]{2}{*}{ Nation } & \multirow[b]{2}{*}{ Year } & \multirow[b]{2}{*}{$\begin{array}{l}\text { Pathogens/disease } \\
\text { considered } \\
\text { (community cases, } \\
\text { unless specified } \\
\text { otherwise) }\end{array}$} & \multirow[b]{2}{*}{$\begin{array}{l}\text { Cases per } \\
\text { year }\end{array}$} & \multicolumn{4}{|c|}{ Costs included $^{\mathrm{a}}$} & \multirow[b]{2}{*}{$\begin{array}{l}\text { Exchange } \\
\text { rate used } \\
(€ 1=\ldots)^{\mathrm{c}}\end{array}$} & \multirow[b]{2}{*}{$\begin{array}{l}\text { Direct } \\
\text { healthcare } \\
\text { cost, per } \\
\text { case (in } € \text { ) }\end{array}$} & \multirow[b]{2}{*}{$\begin{array}{l}\text { Direct } \\
\text { healthcare } \\
\text { cost, yearly } \\
\text { (in million } € \text { ) }\end{array}$} & \multirow[b]{2}{*}{$\begin{array}{l}\text { Total costs } \\
\text { per case } \\
\text { (in } € \text { ) }\end{array}$} & \multirow[b]{2}{*}{$\begin{array}{l}\text { Total yearly } \\
\text { costs (in } \\
\text { million } € \text { ) }\end{array}$} \\
\hline & & & & & $\begin{array}{l}\text { Direct } \\
\text { healthcare } \\
\text { cost }\end{array}$ & $\begin{array}{l}\text { Patient } \\
\text { costs } \\
\text { (e.g. } \\
\text { travel } \\
\text { costs) }\end{array}$ & $\begin{array}{l}\text { Productivity } \\
\text { losses }\end{array}$ & Others $^{\mathrm{b}}$ & & & & & \\
\hline $\begin{array}{l}\text { Lindqvist, } \\
2001[19]\end{array}$ & $\begin{array}{l}\text { Municipality } \\
\text { of Uppsala, } \\
\text { Sweden }\end{array}$ & 1999 & $\begin{array}{l}\text { Foodborne } \\
\text { illnesses }\end{array}$ & $\begin{array}{l}500000^{\mathrm{i}} \\
(\text { Sweden) }\end{array}$ & $\mathrm{X}$ & & $\mathrm{X}$ & & SEK $8 \cdot 81$ & 117 & $58^{\mathrm{d}}$ & 246 & 123 \\
\hline $\begin{array}{l}\text { Scott, } 2000 \\
{[20]}\end{array}$ & New Zealand & 1999 & $\begin{array}{l}\text { Foodborne } \\
\text { infectious disease }\end{array}$ & 119320 & $\mathrm{X}$ & $\mathrm{X}$ & $X$ & $\mathrm{X}$ & NZD $2 \cdot 01$ & $9^{\mathrm{d}}$ & $1 \cdot 0$ & 229 & 27 \\
\hline $\begin{array}{l}\text { Karve, } 2014 \\
{[21]}\end{array}$ & United States & $2010 / 11$ & $\begin{array}{l}\text { Acute } \\
\text { gastroenteritis; } \\
\text { only cases } \\
\text { consulting a } \\
\text { physician, } \\
\text { visiting } \\
\text { emergency } \\
\text { department and } \\
\text { inpatient care } \\
\text { setting }\end{array}$ & $6668944^{j}$ & $\mathrm{X}$ & & & & USD $1 \cdot 36$ & $472^{\mathrm{d}}$ & 3151 & 472 & 3151 \\
\hline
\end{tabular}

\footnotetext{
${ }^{\text {a }}$ Categories represent only a very broad classification of costs included in the studies. Certain items may be included in different categories, depending on the study. For example, transportation cost was sometimes considered as 'direct healthcare cost' (when covered by the health system) and sometimes included in 'patient costs'.

${ }^{\mathrm{b}}$ For example, food recalls, or intangible costs for reduced quality of life (intangible costs are monetary representations of pain, suffering and fear which can be obtained through willingness-to-pay studies [22]), or value of statistical life for premature deaths.

${ }^{c}$ Average exchange rates of the calendar year when the study was conducted (as indicated in the column 'year') were used and extracted from [23].

${ }^{\mathrm{d}}$ Calculated based on yearly case numbers and either costs per case (for calculating yearly costs) or yearly costs (for calculating costs per case) as reported in the original publication.

${ }^{\mathrm{e}}$ Exchange rate as indicated in the original publication (1 Maltese lira $\left.=€ 2 \cdot 29\right)$.

${ }^{\mathrm{f}}$ According to Hall et al. 2005 [24].

${ }^{\mathrm{g}}$ Calculated based on a population size of 490290 and 126320 cases/100 000 population as reported in the original publication.

${ }^{\mathrm{h}}$ Calculated based on total yearly costs (£742.8 million) divided by total costs per case (£79) as reported in the original publication, rounded to the next 100000 .

${ }^{i}$ According to Norling, 1994 [25].

${ }^{\mathrm{j}}$ Sum of estimated annual episodes of acute gastroenteritis in physician's office (5 337 473), emergency department (1 032 064$)$ and inpatients (447 580) as reported in the original publication.
} 
Table 2. Overview of selected studies estimating the cost of illness of campylobacteriosis

\begin{tabular}{|c|c|c|c|c|c|c|c|c|c|c|c|c|c|c|}
\hline \multirow[b]{2}{*}{$\begin{array}{l}\text { First } \\
\text { author, } \\
\text { year [ref.] }\end{array}$} & \multirow[b]{2}{*}{ Nation } & \multirow[b]{2}{*}{ Year } & \multirow[b]{2}{*}{$\begin{array}{l}\text { Pathogens/disease } \\
\text { considered } \\
\text { (community cases, unless } \\
\text { specified otherwise) }\end{array}$} & \multirow[b]{2}{*}{$\begin{array}{l}\text { Sequelae } \\
\text { considered }\end{array}$} & \multirow[b]{2}{*}{$\begin{array}{l}\text { Cases } \\
\text { per year }\end{array}$} & \multicolumn{4}{|c|}{ Costs included $^{\mathrm{a}}$} & \multirow[b]{2}{*}{$\begin{array}{l}\text { Exchange rate } \\
\text { used }(€ 1=\ldots)^{\mathrm{c}}\end{array}$} & \multirow[b]{2}{*}{$\begin{array}{l}\text { Direct } \\
\text { healthcare } \\
\text { cost, per } \\
\text { case (in } € \text { ) }\end{array}$} & \multirow[b]{2}{*}{$\begin{array}{l}\text { Direct } \\
\text { healthcare } \\
\text { cost, yearly } \\
\text { (in million } \\
€ \text { ) }\end{array}$} & \multirow[b]{2}{*}{$\begin{array}{l}\text { Total } \\
\text { costs } \\
\text { per } \\
\text { case } \\
(\text { in } €)\end{array}$} & \multirow[b]{2}{*}{$\begin{array}{l}\text { Total yearly } \\
\text { costs (in } \\
\text { million } € \text { ) }\end{array}$} \\
\hline & & & & & & $\begin{array}{l}\text { Direct } \\
\text { healthcare } \\
\text { cost }\end{array}$ & $\begin{array}{l}\text { Patient } \\
\text { costs } \\
\text { (e.g. } \\
\text { travel } \\
\text { costs) }\end{array}$ & $\begin{array}{l}\text { Productivity } \\
\text { losses }\end{array}$ & Others $^{\mathrm{b}}$ & & & & & \\
\hline $\begin{array}{l}\text { Hoffmann, } \\
2015[10]\end{array}$ & $\begin{array}{r}\text { United } \\
\text { States }\end{array}$ & 2013 & $\begin{array}{l}\text { Campylobacter spp.; only } \\
\text { domestically acquired } \\
\text { and foodborne cases }\end{array}$ & GBS & $845024^{\mathrm{f}}$ & $\mathrm{X}$ & & $\mathrm{X}$ & $\mathrm{X}$ & USD $1 \cdot 34$ & $253^{\mathrm{d}}$ & 213 & 1710 & 1445 \\
\hline $\begin{array}{l}\text { Mangen, } \\
2015[11]\end{array}$ & Netherlands & 2011 & Campylobacter spp. & $\begin{array}{l}\text { GBS, ReA, } \\
\text { IBS, IBD }\end{array}$ & 108000 & $\mathrm{X}$ & $\mathrm{X}$ & $\mathrm{X}$ & & EUR 1 & $280^{\mathrm{d}}$ & 30 & 757 & 82 \\
\hline $\begin{array}{l}\text { Scharff, } \\
2012[12]\end{array}$ & $\begin{array}{c}\text { United } \\
\text { States }\end{array}$ & 2010 & $\begin{array}{l}\text { Campylobacter spp.; only } \\
\text { domestically acquired } \\
\text { and foodborne cases }\end{array}$ & GBS, ReA & $845024^{\mathrm{e}}$ & $X$ & & $\mathrm{X}$ & $X$ & USD $1 \cdot 33$ & 163 & $138^{\mathrm{d}}$ & $\begin{array}{r}1392- \\
6141\end{array}$ & $1177-5189$ \\
\hline $\begin{array}{l}\text { Gellynck, } \\
2008[26]\end{array}$ & Belgium & 2004 & $\begin{array}{l}\text { Campylobacter-associated } \\
\text { gastroenteritis and } \\
\text { sequelae }\end{array}$ & $\begin{array}{l}\text { GBS, ReA, } \\
\text { IBD }\end{array}$ & 55000 & $\mathrm{X}$ & $\mathrm{X}$ & $\mathrm{X}$ & & EUR 1 & n.a. & n.a. & $497^{\mathrm{d}}$ & 27 \\
\hline $\begin{array}{l}\text { Mangen, } \\
2005[8]\end{array}$ & Netherlands & 2000 & $\begin{array}{l}\text { Campylobacter spp. and } \\
\text { sequelae }\end{array}$ & $\begin{array}{l}\text { GBS, ReA, } \\
\text { IBD }\end{array}$ & 79000 & $\mathrm{X}$ & $\mathrm{X}$ & $\mathrm{X}$ & & EUR 1 & $82^{\mathrm{d}}$ & $6 \cdot 5$ & $261^{\mathrm{d}}$ & 21 \\
\hline $\begin{array}{l}\text { Van den } \\
\text { Brandhof, } \\
2004[17]\end{array}$ & Netherlands & 1999 & Campylobacter spp. & $\begin{array}{l}\text { Not } \\
\text { considered }\end{array}$ & $79000^{\mathrm{f}}$ & $\mathrm{X}$ & $\mathrm{X}$ & $\mathrm{X}$ & & EUR 1 & n.a. & n.a. & $117^{\mathrm{d}}$ & 9 \\
\hline $\begin{array}{l}\text { Scott, } 2000 \\
{[20]}\end{array}$ & $\begin{array}{l}\text { New } \\
\text { Zealand }\end{array}$ & 1999 & $\begin{array}{l}\text { Proportion of foodborne } \\
\text { Campylobacter spp. }\end{array}$ & $\begin{array}{l}\text { GBS, ReA, } \\
\text { HUS }\end{array}$ & 75345 & $\mathrm{X}$ & $\mathrm{X}$ & $\mathrm{X}$ & $\mathrm{X}$ & NZD $2 \cdot 01$ & $8^{\mathrm{d}}$ & $0 \cdot 6$ & 265 & 20 \\
\hline $\begin{array}{l}\text { Roberts, } \\
2003[18]\end{array}$ & England & 1994 & Campylobacter spp. & $\begin{array}{l}\text { Not } \\
\text { considered }\end{array}$ & n.a. & $X$ & $\mathrm{X}$ & $X$ & & $\begin{array}{l}\text { GBP } 0.66 \\
\text { (year 1999) }\end{array}$ & n.a. & 15 & n.a. & 106 \\
\hline
\end{tabular}

GBS, Guillain-Barré Syndrome; HUS, haemolytic uraemic syndrome; IBD, inflammatory bowel disease; IBS, irritable bowel syndrome; n.a., not available; ReA, reactive arthritis.

${ }^{a}$ Categories represent only a very broad classification of costs included in the studies. Certain items may be included in different categories, depending on the study. For example, transportation cost was sometimes considered as 'direct healthcare cost' (when covered by the health system) and sometimes included in 'patient costs'.

${ }^{\mathrm{b}}$ For example, food recalls, or intangible costs for reduced quality of life (intangible costs are monetary representations of pain, suffering and fear which can be obtained through willingness-to-pay studies [22]), or value of statistical life for premature deaths.

${ }^{c}$ Average exchange rates of the calendar year when the study was conducted (as indicated in the column 'year') were used and extracted from [23].

${ }^{\mathrm{d}}$ Calculated based on yearly case numbers and either costs per case (for calculating yearly costs) or yearly costs (for calculating costs per case) as reported in the original publication.

e According to Scallan et al. 2011 [27].

${ }^{\mathrm{f}}$ Assumed, according to Mangen et al. 2005 [8]. 


\section{Population figures as basis for modelling: sources and approach}

The number of notified campylobacteriosis cases occurring each year in Switzerland was retrieved from the NNSID [1]. A study assessing the trend in Campylobacter positivity rates was conducted (thereafter referred to as the 'Positivity study'). This study used data of eight Swiss diagnostic laboratories on Campylobacter tests performed between 2003 and 2012. Positivity rates, defined as the proportion of Campylobacter-positive to total number of Campylobacter tests, were calculated. The number of Campylobacter tests performed in Switzerland was estimated based on the preliminary positivity rate of 2012 .

In 2013, a qualitative study among 69 GPs was conducted in Switzerland (thereafter referred to as the 'Swiss GP study'). Using a semi-structured questionnaire, physicians were interviewed about their case management strategies for and general perception of AG and campylobacteriosis. From this study, GPs' estimates on the proportion of AG patients with a stool test prescribed were available.

In 2014, the Swiss Sentinel Surveillance Network decided to study AG for 12 months; 170 participating GPs reported all cases consulting due to AG. This study (thereafter referred to as the 'Sentinella study') also provides estimates on the proportion of patients with a stool test.

The results used for cost estimates from the 'Positivity', the 'Swiss GP' and the 'Sentinella study' are preliminary. Short summaries of these studies including the preliminary results used for estimating healthcare costs can be found in the Supplementary material. Final results of all these studies will be published separately.

We used the number of hospitalizations due to the ICD-10 code 'A04.5 Campylobacter enteritis' as reported in official hospital statistics published by the Federal Statistical Office [31]. We compared this number with estimates based on the hospitalization rate found in our case-control study on determinants of campylobacteriosis [29] and the number of campylobacteriosis case notifications from the NNSID [1].

\section{Population-level estimates}

The number of campylobacteriosis cases registered at the FOPH was assumed to correspond to the number of patients in management models $\mathrm{C}$ and $\mathrm{D}$ in the whole of Switzerland. The number of hospitalizations in Switzerland (patient management model D) was extracted from official hospital statistics (hospitalizations due to Campylobacter enteritis, ICD-10 code A04.5) [31].

Patients in management model D

$=$ cases hospitalized due to ICD-10 code A04.5,

Patients in management model $\mathrm{C}=$ cases in NNSID

- patients in management model D.

The proportion of positive to total number of campylobacteriosis tests was used to estimate the number of patients in management model B based on notified cases (hence, cases with a positive test result).

Patients in management model B

$$
\begin{aligned}
& =\frac{\text { cases in NNSID }}{\text { positivity rate }\left(=\frac{\text { positive tests in } x \text { labs }}{\text { all tests in } x \text { labs }}\right)} \\
& - \text { cases in NNSID. }
\end{aligned}
$$

The proportion of patients with stool testing (as opposed to consultation without stool testing) was used to estimate case numbers for patient management model A.

Patients in management model A

$$
\begin{aligned}
= & {\left[\frac{\left(\begin{array}{c}
\text { patients in management model } \mathrm{B}+ \\
\text { cases in NNSID }(=\text { all tested })
\end{array}\right)}{\text { proportion of patients with stool test }}\right] } \\
& - \text { all tested. }
\end{aligned}
$$

The data sources used for the extrapolation from individual to population-based costs are summarized in Figure $1 a$.

\section{Healthcare expenditures}

Healthcare costs for each of the patient management models were estimated by combining associated medical standard procedures with publicly available respective rates for accounting. We extrapolated these individual case management costs to estimate healthcare costs associated with $\mathrm{AG}$ and campylobacteriosis in Switzerland in 2012.

\section{Sources of cost data}

We used different sources in order to calculate healthcare expenditure due to Campylobacter infections: from the Swiss GP study, based on expert opinions and using preliminary results of the Sentinella study, treatment schemes and standard approaches for case management (including number and duration of 
(a) Extrapolation to population-based estimates

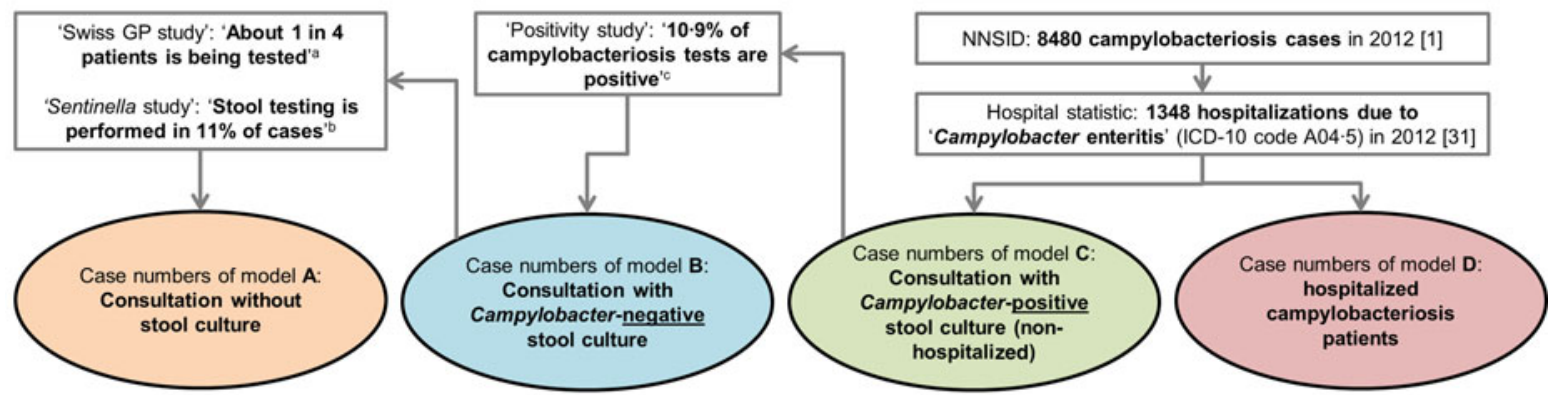

(b) Cost estimation process for individual cases / patient management models

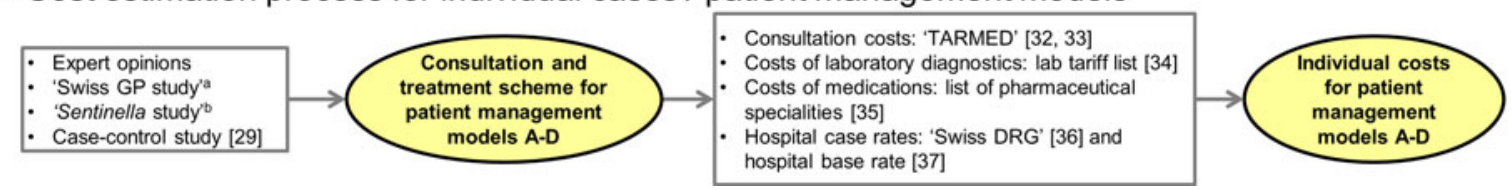

Fig. 1. Overview of data sources used for $(a)$ extrapolation of treatment costs and $(b)$ for cost estimation for acute gastroenteritis and campylobacteriosis patients. ${ }^{\text {a }}$ Qualitative study about case management of campylobacteriosis patients among 69 general practitioners in Switzerland (Supplementary material). ${ }^{\mathrm{b}}$ Study on acute gastroenteritis conducted within the Swiss Sentinel Surveillance Network 'Sentinella' (www.sentinella.ch) in 2014 (Supplementary material). ${ }^{c}$ Study on laboratory positivity rates of Campylobacter, Salmonella and Shigella diagnostic tests in Switzerland (Supplementary material).

consultations, laboratory tests performed and medications prescribed) were identified. Consultation costs of GPs were calculated using the number of points from the publicly available Swiss medical tariff system, TARMED (as of June 2012) [32] and a point value of $€ 0.7138$ which is used in the canton of Bern [33]. Similarly, points for laboratory diagnostics were extracted from the official tariff list ('Analysenliste'; as of January 2012) using a point value of $€ 0.83$ applied throughout Switzerland [34]. Costs for medications were extracted from the list of pharmaceutical specialities ('Spezialitätenliste', version of 1 January 2012) [35]. Calculation of hospitalization costs was based on the flat rates of the Swiss diagnosis-related group-based (DRG-based) hospital reimbursement system and a base rate which is applied by several regional hospitals in the canton of Bern, both for 2012 [36, 37]. Costs in Swiss francs were converted to Euros using an exchange rate for the Euro of $€ 0.83$ per Swiss franc (average exchange rate January 2012-December 2012) [23]. The cost estimation process for the patient management models is presented in Figure $1 b$.

We obtained primary cost data from invoices for consultations of Campylobacter-positive patients, covering all patient consultations between 2011 and 2013 at the Swiss TPH travel clinic. This part of the study was approved by the local ethical committee (Ethikkommission Nordwest- und Zentralschweiz ref. no. EKNZ: 2014-159).

\section{Data analysis}

\section{Costs per patient treated}

Differentiating by patient management model (models A-D), we evaluated the costs for consultations, medication, laboratory tests and hospitalization until conclusion of medical treatment. For all patient management models we defined two scenarios to account for some of the heterogeneity of the patients and the case management strategies within a given model: a minimal and an extended or prolonged scenario. The proportions of patients treated with the minimal and the extended scenario were estimated based on results of the case-control (e.g. proportion of patients treated with antibiotics) [29] and the Sentinella study (e.g. number of consultations; Supplementary material). Afterwards, experts were asked whether they considered the estimated proportions reasonable. The two scenarios do not imply any chronology of the steps involved.

Estimates for patient management model $\mathrm{C}$ were validated using real patient records of the Swiss TPH travel clinic. Patient invoices were entered in an electronic database and analysed using Stata v. 13 (StataCorp., USA). Costs for laboratory tests or medication not primarily associated with AG were excluded, i.e. tests for Echinococcus, Filaria, flavivirus and Plasmodium, vaccines for rabies and tetanus, and electrocardiograms. Laboratory tests performed in external laboratories were invoiced by these laboratories and 


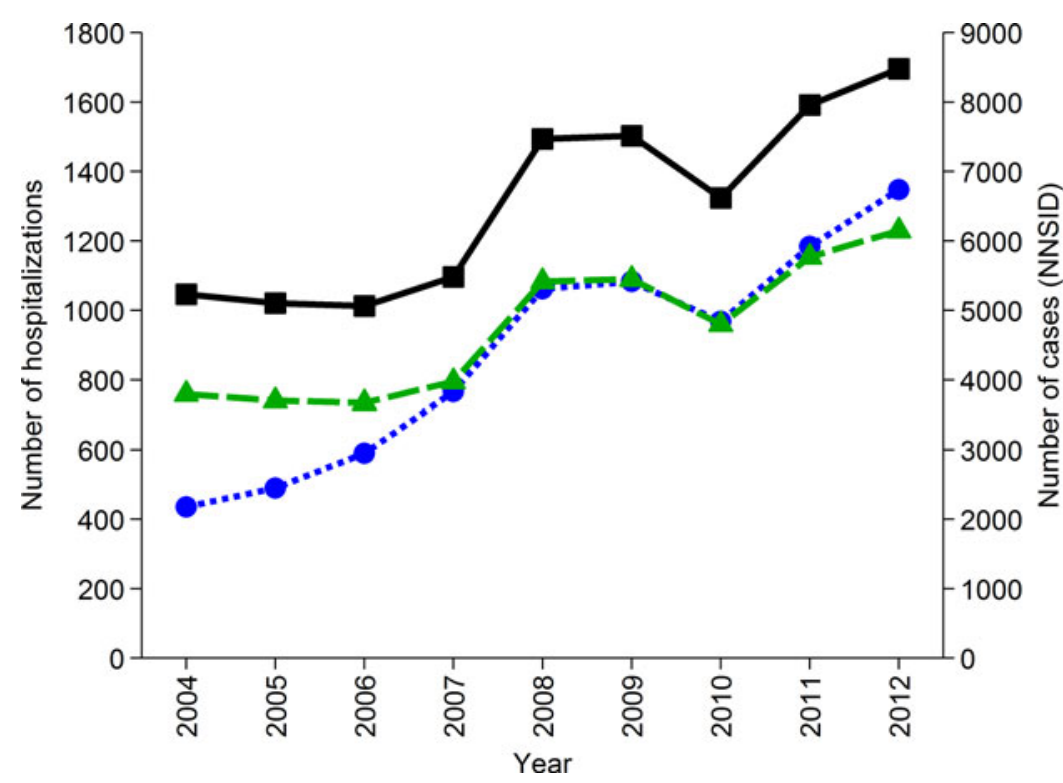

Fig. 2. Number of hospitalizations due to ICD-10 code A04.5 'Campylobacter enteritis' in Switzerland from 2004 to 2012 (๑....., left axis, [31]), number of hospitalizations extrapolated from results of a case-control study in Switzerland [29] assuming hospitalization of $14.5 \%$ of cases registered in the National Notification System for Infectious Diseases (NNSID) ( $\triangle-\Delta$, left axis) and number of case notifications from the NNSID [1] ( $\square$; right axis).

could, hence, not be considered in our analysis. However, we added costs for one positive stool test for Campylobacter spp. as patients were selected based on having laboratory-confirmed campylobacteriosis.

\section{RESULTS}

Frequency of different patient management models in Switzerland

In the NNSID, 8480 cases of campylobacteriosis were registered in 2012 [1]. Preliminary results from the Positivity study showed that $10 \cdot 9 \%$ of all campylobacteriosis tests were positive (Supplementary material). Consequently, we estimated that 77798 tests for Campylobacter spp. were made in 2012, of which 69318 had a negative test result (patient management model B). Estimates of the Swiss GP study indicated that one in four AG patients has a stool test performed (Supplementary material), suggesting that 233394 patients consult a physician each year without further stool testing (patient management model A). However, preliminary results from the Sentinella study suggest that only $11 \%(420 / 3794)$ of patients had stool testing performed (Supplementary material). In this case a total of 629457 patients would be in patient management model $\mathrm{A}$.

The number of hospitalizations due to 'Campylobacter enteritis' (ICD-10 code A04.5) as reported in the official Swiss hospital statistics increased steadily since 2004. In 2012, 1348 hospitalizations were reported which is the maximum so far (Fig. 2). For comparison, $14 \cdot 5 \%$ (23/159) of interviewed patients in the recent case-control study, with laboratoryconfirmed campylobacteriosis, reported hospitalization due to their illness [29]. Considering the case notification numbers of 2012 (8480 cases), this proportion would result in 1230 hospitalizations (patient management model D). Patient management model C includes all notified cases except those being hospitalized (1348), resulting in 7132 patients annually in Switzerland.

\section{Individual case management costs for AG and campylobacteriosis patients}

The costs per case are highly variable ranging from $€ 30$ (patient management model A) to $€ 4828$ (patient management model D). The cost items attributed to the different patient management models and scenarios and associated costs are presented in Table 3. (For a list of unit costs see Supplementary Table S2.)

The healthcare costs of 41 patients with laboratoryconfirmed Campylobacter spp. infection were analysed. Costs for those 19 male and 22 female patients aged between 1 and 72 years were in the range of $€ 179-1033$ (median $€ 464$ ). The number of consultations varied between 1 and 8 per patient (median 2), 
Table 3. Healthcare costs associated with the management of acute gastroenteritis and campylobacteriosis for four patient management models with two scenarios each (values reflect costs in $€$ )

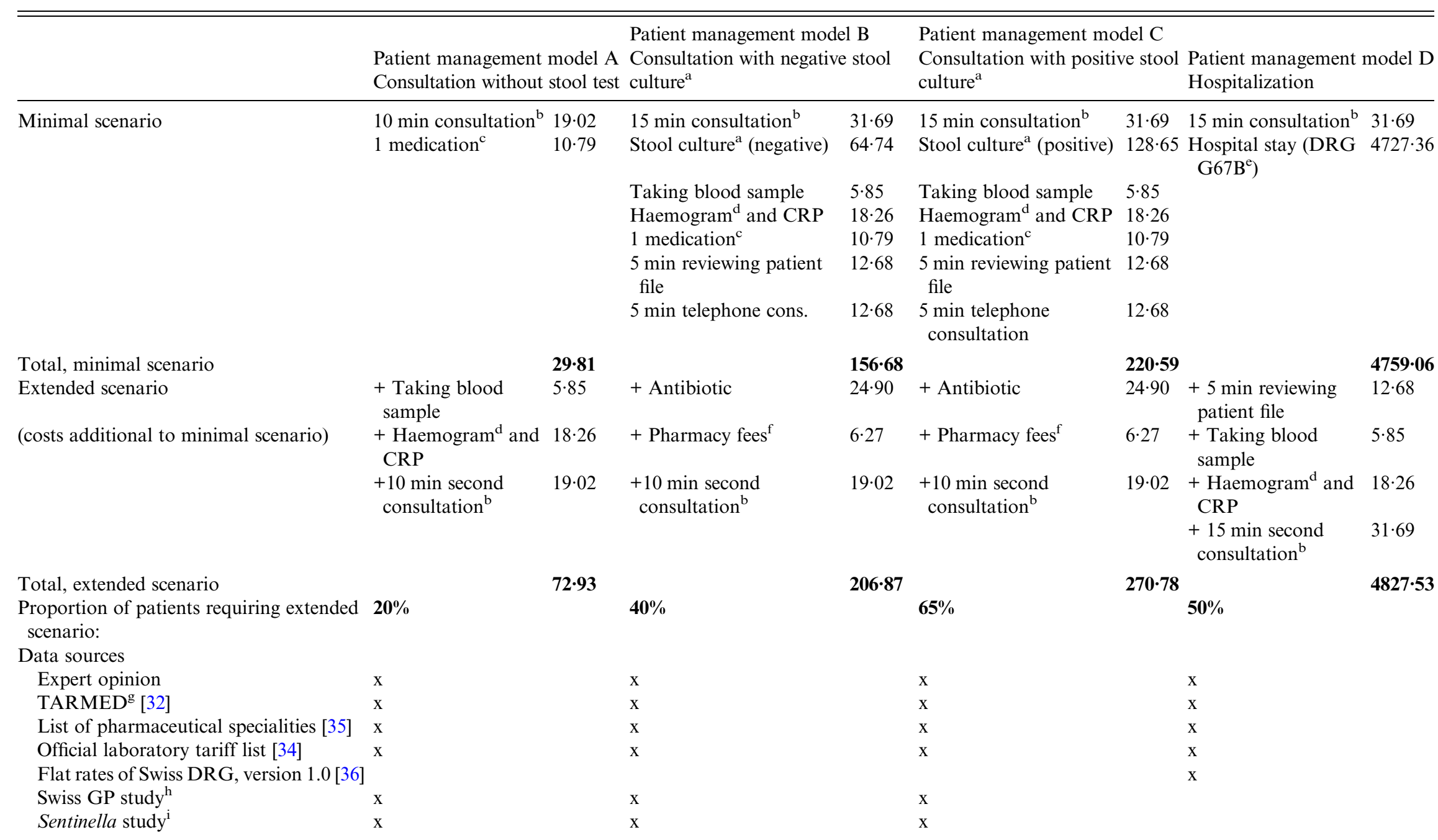


Table 3 (cont.)

\begin{tabular}{lll}
\hline \hline & $\begin{array}{l}\text { Patient management model B } \\
\text { Patient management model A } \begin{array}{l}\text { Consultation with negative stool } \\
\text { Consultation without stool test culture }\end{array}\end{array}$ & $\begin{array}{l}\text { Patient management model C } \\
\text { Consultation with positive stool Patient management model D } \\
\text { culture }^{\mathrm{a}}\end{array}$ \\
\hline Swiss TPH travel clinic & & $\mathrm{x}$ \\
\hline \hline
\end{tabular}

CRP, C-reactive protein; NNSID, National Notification System for Infectious Diseases.

a Stool culture includes Campylobacter, Salmonella and Shigella.

${ }^{\mathrm{b}}$ Or telephone consultation of same duration.

${ }^{\mathrm{c}}$ Of the following medications: antidiarrhoeal, antiemetics, probiotics; average price of those medications: $€ 10 \cdot 79$ (13 CHF).

${ }^{\mathrm{d}}$ Including erythrocytes, leucocytes, haemoglobin, haematocrit, thrombocytes, and $\geqslant 5$ subpopulations of leucocytes.

${ }^{\mathrm{e}}$ For a patient with Campylobacter enteritis (ICD-10 code A04-5), aged $\geqslant 1$ year, with a length of stay between 2 and 11 nights, the DRG group 'G67B' is assigned. Cost weight: 0.573, base rate (applied by several regional hospitals in Bern): €8250.20 (9940 CHF) [37]. Quote from Swiss DRG version 1.0 [36] defining code 'G67B': [translated from German] 'Oesophagitis, gastroenteritis and other diseases of the digestive organs with a complex diagnosis or age $<1$ year or gastrointestinal bleeding, with very severe or severe complications or comorbidities or age $>74$ years or peptic ulcer disease with severe complications or comorbidities or age $>74$ year, hospital occupancy $>1$ day, without complicating diagnosis, without dialysis'.

${ }^{\mathrm{f}}$ Fees include check of the prescription which can be invoiced once per item prescribed ('Medikamenten-Check'; €3.57, CHF 4.30) and check of the purchase which can be invoiced once per patient, per day and per provider ('Bezugs-Check'; €2·70, CHF 3.25) [49].

${ }^{\mathrm{g}}$ Costs vary among cantons; median costs are used (tariff point value $€ 0.7138$ or $0 \cdot 86 \mathrm{CHF}$, e.g. canton Bern) [33].

${ }^{\mathrm{h}}$ Qualitative study about case management of campylobacteriosis patients among 69 general practitioners in Switzerland (Supplementary material).

${ }^{\mathrm{i}}$ Study on acute gastroenteritis conducted within the Swiss Sentinel Surveillance Network 'Sentinella' (www.sentinella.ch) in 2014 (Supplementary material). 
Table 4. Estimated healthcare costs for the treatment of acute gastroenteritis and campylobacteriosis in Switzerland. Costs for individual cases are based on resource use estimates presented in Table 3

\begin{tabular}{|c|c|c|c|c|c|}
\hline & $\begin{array}{l}\text { Patient } \\
\text { management } \\
\text { model } \mathrm{A}_{\text {Sentinella }}\end{array}$ & $\begin{array}{l}\text { Patient } \\
\text { management } \\
\text { model } A_{\text {Swiss GP }}\end{array}$ & $\begin{array}{l}\text { Patient } \\
\text { management } \\
\text { model B }\end{array}$ & $\begin{array}{l}\text { Patient } \\
\text { management } \\
\text { model C }\end{array}$ & $\begin{array}{l}\text { Patient } \\
\text { management } \\
\text { model D }\end{array}$ \\
\hline Estimated number of cases $(n)$ & 629457 & 233394 & 69318 & 7132 & 1348 \\
\hline In minimal scenario & 503566 & 186715 & 41591 & 2496 & 674 \\
\hline In extended scenario & 125891 & 46679 & 27727 & 4636 & 674 \\
\hline Consultation & $€ 11969523$ & $€ 4438134$ & $€ 4359611$ & $€ 448552$ & $€ 42722$ \\
\hline Laboratory diagnostics & $€ 0$ & $€ 0$ & $€ 5753394$ & $€ 1047762$ & $€ 0$ \\
\hline Medication & $€ 6791841$ & $€ 2518321$ & $€ 747941$ & $€ 76954$ & $€ 0$ \\
\hline Hospitalization & $€ 0$ & $€ 0$ & $€ 0$ & $€ 0$ & $€ 6372487$ \\
\hline+ Consultation & $€ 3129858$ & $€ 1160517$ & $€ 527246$ & $€ 88156$ & $€ 33845$ \\
\hline +Laboratory diagnostics & $€ 2298770$ & $€ 852359$ & $€ 0$ & $€ 0$ & $€ 12307$ \\
\hline+ Medication & $€ 0$ & $€ 0$ & $€ 864154$ & $€ 144488$ & $€ 0$ \\
\hline $\begin{array}{l}\text { Healthcare costs by patient } \\
\text { management model }\end{array}$ & $€ 24189992^{\mathrm{a}}$ & $€ 8969331^{\mathrm{a}}$ & $€ 12252346^{\mathrm{a}}$ & $€ 1805913^{\mathrm{a}}$ & $€ 6461362^{\mathrm{a}}$ \\
\hline Total healthcare costs & \multicolumn{5}{|c|}{$€ 29488953-44709613^{a}$} \\
\hline
\end{tabular}

a Totals do not always add up because of rounding.

the number of blood samples taken between 0 and 4 (median 1) and the time between the first and the last consultation between 0 (only one consultation) and 65 days (median 3). Consultation costs and costs for laboratory testing of real patient data were higher than estimated costs for patient management model C (Supplementary Table S3).

\section{Healthcare costs due to AG and campylobacteriosis}

Total healthcare costs for the management of the four different patient management models combined in Switzerland in 2012 were estimated at $€ 29 \cdot 5-44.7$ million (Table 4). Costs for the different patient management model groups (A-D) were €9.0-24.2, €12.3, $€ 1.8$ and $€ 6.5$ million, respectively (Supplementary Fig. S1).

Costs separated by type/provider were: $€ 11 \cdot 1-20 \cdot 6$ million for GPs' services (including medical assistants), €7.7-9.1 million for laboratory diagnostics, $€ 4 \cdot 4-8.6$ million for medications and $€ 6.4$ million for hospitalizations (Supplementary Fig. S2).

\section{DISCUSSION}

This study provides for the first time an assessment of total Swiss healthcare costs due to AG and campylobacteriosis by estimating the individual costs of four types of patient management models and their frequency: patients suffering from AG and seeking medical care without being tested (model A); patients seeking medical care and having a Campylobacter-negative stool test (model B); patients seeking medical care and having a Campylobacter-positive stool test (model C); and patients with a severe course of campylobacteriosis requiring hospitalization (model D).

Cases of campylobacteriosis increased in the last decade $1 \cdot 5$-fold, implying a contemporarily relevant public health problem. We estimated that in Switzerland, each year 311 192-707 255 patients consult a physician due to AG or campylobacteriosis, leading to annual healthcare costs ranging from $€ 29$ to $€ 45$ million.

The calculations were based on several assumptions as this study provides the first estimates of healthcare costs due to $\mathrm{AG}$ and campylobacteriosis in Switzerland. The country has no central database which is based on diagnostic codes and where healthcare costs from outpatient care are systematically recorded. Therefore, we tried to cross-validate our estimates whenever possible by combining different data sources. The real patient data which we used for comparison with cost estimates for patient management model $\mathrm{C}$ originated from our own institution's (Swiss TPH) travel clinic. These real patient data suggested higher costs for laboratory-confirmed, ambulatory patients than we used for our calculations. Possibly consultation time in returning travellers was longer because of the travel anamnesis and laboratory tests were more extensive. Nevertheless, returning travellers are likely to be overrepresented also in the patients with AG seen by GPs. When using the 
median total costs of the real patient data of the travel clinic for patients in management model $\mathrm{C}$, the costs for this group would be $€ 3.3$ million (instead of $€ 1.8$ million; Supplementary Figs S1 and S2). Hence, we believe the cost estimates used for patient management model $\mathrm{C}$ are conservative.

Some physicians reported performing a second stool test after a positive result for certain patient groups (e.g. working in the food sector) before allowing the patients to return to work. A few experts claimed that the consultation times we applied in our models were rather short. They suggested consultation times of 5-10 min longer for selected (but not for all) consultations. The case-control study [29] found that about $10 \%$ of campylobacteriosis patients in outpatient treatment received intravenous therapy, which was not considered in our models. Furthermore, patients requiring hospitalization may be transferred to the hospital by ambulance causing additional costs. Taking all these points into account, we believe that our estimates reflect rather conservative approximations.

\section{Healthcare costs of laboratory-confirmed campylobacteriosis patients}

Campylobacteriosis cases as registered in the NNSID were estimated to cost around $€ 8.3$ million/year (patient management models $\mathrm{C}$ and $\mathrm{D}$ ). The majority of these costs are attributable to hospitalizations. Comparison of our estimates with actual patient data suggests that our estimates (at least for patient management model C) underestimated actual costs occurring in the health system. The number of hospitalizations due to 'Campylobacter enteritis' (ICD-10 code A04.5) matches well with the calculated number of hospitalized patients using the official notification data together with the hospitalization rate found in the case-control study (1348 vs. 1230 cases). The hospitalization costs, which are based on DRG flat rates, include all costs occurring during the hospital stay. This flat rate is independent of the length of stay as long as it is within 2-11 nights (for DRG code G67B, according to DRG v. 1.0 [36]).

\section{Healthcare costs of AG patients}

The costs for AG patients without laboratoryconfirmed campylobacteriosis varied significantly depending on the proportion of stool testing we used to calculate patient numbers for patient management model A. The proportion of stool testing is highly variable also in other countries: it was found to be $12 \%$ in The Netherlands [38], $19-44 \%$ in the United States [39, 40] and 27\% in England [41]. Even though our estimate of $11 \%$ from the Sentinella study is lower compared to the proportions reported in other countries we believe that this number is more accurate than the semi-quantitative estimates obtained from the Swiss GP study. Moreover, the figure from the Sentinella study represents the proportion of patients for which the physician initiated stool testing. It is likely that not all patients actually provided a stool specimen. Hence, using the proportion of actually completed stool tests would increase case numbers in model A and our cost estimates. Additionally, our calculation for patient management model $\mathrm{A}$ is based on the estimated number of tests for Campylobacter spp. This may in fact underestimate the total number of stool tests as in some instances physicians might only test their patients for viruses, for example. In this case, the number of patients in management models $\mathrm{A}$ and $\mathrm{B}$ would be even larger.

Apart from Campylobacter both Salmonella and Shigella infections are notifiable in Switzerland. Usually, basic stool bacteriology involves testing for these three pathogens [42]. Under this assumption and ignoring the chance of mixed infections, all Salmonella- or Shigella-positive patients were assigned to management model B (patients with Campylobacter-negative stool test). This leads again to a rather conservative estimate of costs since stool cultures with a positive result are more expensive than negative stool cultures (€64.74 vs. €128.65) [34]. Additionally, salmonellosis and shigellosis patients may also need hospitalization and those patients are, therefore, more likely to create costs similar to those estimated for campylobacteriosis patient management models C and D. In 2012, 1243 cases of salmonellosis and 159 cases of shigellosis were reported [43, 44]. Moreover, AG patients with viral infections and patients without an identified causative agent might be hospitalized. The hospitalization costs for these patients were not considered in our study.

Patients consulting a physician not at all or only by phone and patients seeking help in a pharmacy have not been considered in this study. Up to $60 \%$ of gastroenteritis patients calling the medical practice are managed by phone, according to the Swiss GP study (Supplementary material). Individual (healthcare) costs for these patients may be low. However, the high quantity of these patients might still lead to considerable costs. 


\section{Comparison of cost estimates for Switzerland with estimates of other countries}

Various studies have been conducted in several countries to estimate costs for gastrointestinal infections or campylobacteriosis (Tables 1 and 2). However, comparison of costs is very difficult due to varying case definitions used, heterogeneity in costs included, differences in health systems and health-system use and time. We estimated that a case of laboratoryconfirmed campylobacteriosis costs on average $€ 975$ (average per case for models C and D). The extent of underreported campylobacteriosis infections defined as infections in individuals who seek healthcare but whose infection is not captured by the surveillance system [45] - is unknown for Switzerland. The multiplication factor due to underreporting of campylobacteriosis was estimated at 1.3 in the UK [46] and at $2 \cdot 0-5 \cdot 6$ in The Netherlands [6, 47]. Applying the same factors to Swiss data would result in 2544 39008 additional campylobacteriosis cases. Assuming that underreporting was due to under-diagnosis (as opposed to under-notification), these cases are automatically included in our patient management model A (where model A represents all consulting AG patient without stool diagnostics.) Hence, costs in model A attributable to under-diagnosed campylobacteriosis cases would range between $€ 0.98$ and $€ 1.50$ million. Total costs attributable to campylobacteriosis would then range between $€ 8.4$ and $€ 9.8$ million in Switzerland (representing 19-33\% of total AG costs) or $€ 206-759 /$ case. Healthcare costs per case are higher than Dutch (€82-280/case, Table 2) or US estimates $(€ 163-253 /$ case). However, the latter two were based on the yearly estimated number of campylobacteriosis cases in the population while we considered only campylobacteriosis cases presenting to the GP or being hospitalized.

On average, a case of AG (including campylobacteriosis) in Switzerland was estimated at €63-95. Again, our cost estimates are based on cases presenting to the GP while estimates from other countries usually are presented for cases in the community. Hence, values are not comparable even though our cost estimates are within the range of cost estimates from other countries (€3-155 [9-20], Table 1).

\section{Unknown socioeconomic burden}

We only assessed direct healthcare costs for AG and campylobacteriosis. The average hospital stay of three nights and the median disease duration of 7 days of campylobacteriosis patients which were found in the case-control study [29] suggest that the socioeconomic burden due to productivity loss and home care is a multiple of the healthcare costs. Additionally, we neither considered costs arising from complications of the disease (e.g. GuillainBarré syndrome, reactive arthritis or irritable bowel syndrome) nor did we include out-of-pocket expenses for medications of patients not consulting a physician or costs arising of patients consulting the physician exclusively by phone. This further underscores the conservative nature of our overall healthcare cost estimated at $€ 29-45$ million.

The disease burden and economic consequences are further increased by years of life lost due to premature mortality. The ICD-10 codes A02 'other Salmonella infections' and A04.5 'Campylobacter enteritis' were recorded only for four patients in 2011 as the main cause of death (Swiss Federal Statistical Office, personal communication). When considering also secondary causes of deaths, 104 deaths were registered in 2011. For influenza it was shown that mortality is underreported in official statistics [48]. We assume that such underreporting is also the case for deaths due to campylobacteriosis (and salmonellosis).

AG and campylobacteriosis cause a marked public health problem generating considerable costs. To our knowledge, this is the first study investigating healthcare costs due to AG and campylobacteriosis in Switzerland. Further research is needed for more accurate cost estimation. In order to reduce the financial burden and suffering of patients, there is a need for implementing health policy measures, sectorial and inter-sectorial public health interventions and increasing awareness in the population at all levels.

\section{SUPPLEMENTARY MATERIAL}

For supplementary material accompanying this paper visit http://dx.doi.org/10.1017/S0950268816001618.

\section{ACKNOWLEDGEMENTS}

The authors gratefully acknowledge Professor Johannes Blum (Swiss TPH), Dr Klaus Bally, Professor Lukas Degen (University Hospital of Basel), Dr Alexandre Kummer and Dr Ursina Halter for sharing their clinical experience and providing feedback to the patient management models. We thank Dr Monika Diebold (Obsan) for providing a critical review of the final 
draft version of the manuscript and Dr Jan Hattendorf for fruitful and stimulating discussions. The help of Dr Hanspeter Marti, Mrs Astrid Haas (both Swiss TPH) and Mrs Heidi Farner (Medibact) in identifying, extracting and blinding patient invoices of campylobacteriosis patients is much appreciated.

This research received no specific grant from any funding agency, commercial or not-for-profit sectors.

\section{DECLARATION OF INTEREST}

None.

\section{REFERENCES}

1. Schmutz C, et al. Inverse trends of Campylobacter and Salmonella in Swiss surveillance data, 1988-2013. Eurosurveillance 2016; 21: pii $=30130$.

2. European Food Safety Authority, European Centre for Disease Prevention and Control. The European Union summary report on trends and sources of zoonoses, zoonotic agents and food-borne outbreaks in 2013. EFSA Journal 2015; 13: 3991, 165 pp.

3. Havelaar AH, et al. Estimating the true incidence of campylobacteriosis and salmonellosis in the European Union, 2009. Epidemiology and Infection 2013; 141: 293-302.

4. The Swiss Federal Council. Ordinance on disease notification of humans from 13 January 1999 (version from 1 January 2014 [in German]. Bern: The Swiss Federal Council, 2014. (http://www.admin.ch/ch/d/sr/8/818.141. 1.de.pdf).

5. Havelaar AH, et al. Disease burden of foodborne pathogens in the Netherlands, 2009. International Journal of Food Microbiology 2012; 156: 231-238.

6. Haagsma JA, et al. Disease burden of post-infectious irritable bowel syndrome in The Netherlands. Epidemiology and Infection 2010; 138: 1650-1656.

7. Buzby JC, Allos BM, Roberts T. The economic burden of Campylobacter-associated Guillain-Barré syndrome. Journal of Infectious Diseases 1997; 176 (Suppl. 2), S192-197.

8. Mangen MJJ, et al. The costs of human Campylobacter infections and sequelae in the Netherlands: a DALY and cost-of-illness approach. Food Economics - Acta Agriculturae Scandinavica, Section C 2005; 2: 35-51.

9. Hellard ME, et al. Cost of community gastroenteritis. Journal of Gastroenterology and Hepatology 2003; 18: 322-328.

10. Hoffmann S, Maculloch B, Batz M. Economic burden of major foodborne illnesses acquired in the United States: U.S. Department of Agriculture, Economic Research Service, 2015 (Economic Information Bulletin No. 140).

11. Mangen MJJ, et al. Cost-of-illness and disease burden of food-related pathogens in the Netherlands, 2011.
International Journal of Food Microbiology 2015; 196: 84-93.

12. Scharff RL. Economic burden from health losses due to foodborne illness in the United States. Journal of Food Protection 2012; 75: 123-131.

13. Friesema IHM, Lugnér AK, van Duynhoven YTHP. Costs of gastroenteritis in the Netherlands, with special attention for severe cases. European Journal of Clinical Microbiology \& Infectious Diseases 2012; 31: 1895 1900.

14. Gauci C, et al. Estimating the burden and cost of infectious intestinal disease in the Maltese community. Epidemiology and Infection 2007; 135: 1290-1298.

15. Abelson P, Potter Forbes M, Hall G. The annual cost of foodborne illness in Australia. Canberra, Australia: Australian Government Department of Health and Ageing, 2006: pp. 97.

16. Majowicz SE, et al. Burden and cost of gastroenteritis in a Canadian community. Journal of Food Protection 2006; 69, 651-659. [Erratum in Journal of Food Protection 2011; 1: 2-2.].

17. van den Brandhof WE, et al. Costs of gastroenteritis in The Netherlands. Epidemiology and Infection 2004; 132: 211-221.

18. Roberts JA, et al. The study of infectious intestinal disease in England: socio-economic impact. Epidemiology and Infection 2003; 130: 1-11.

19. Lindqvist R, et al. A one-year study of foodborne illnesses in the municipality of Uppsala, Sweden. Emerging Infectious Diseases 2001; 7: 588-592.

20. Scott WG, et al. Economic cost to New Zealand of foodborne infectious disease. New Zealand Medical Journal 2000; 113: 281-284.

21. Karve $\mathbf{S}$, et al. Burden of acute gastroenteritis, norovirus and rotavirus in a managed care population. Human Vaccines \& Immunotherapeutics 2014; 10: 1544-1556.

22. Meltzer MI. Introduction to health economics for physicians. Lancet 2001; 358: 993-998.

23. European Central Bank. Euro foreign exchange reference rates (http://www.ecb.europa.eu/stats/exchange/ eurofxref/html/index.en.html). Accessed 15 April 2016.

24. Hall G, et al. Estimating foodborne gastroenteritis, Australia. Emerging Infectious Diseases 2005; 11: 1257-1264.

25. Norling B. Food poisoning in Sweden - results of a field survey. Uppsala, Sweden: National Food Administration, 1994, 41/94.

26. Gellynck X, et al. Economics of reducing Campylobacter at different levels within the Belgian poultry meat chain. Journal of Food Protection 2008; 71: 479-485.

27. Scallan E, et al. Foodborne illness acquired in the United States - major pathogens. Emerging Infectious Diseases 2011; 17: 7-15.

28. European Food Safety Authority. EFSA explains zoonotic diseases: Campylobacter (http://www.efsa.europa.eu/sites/ default/files/corporate_publications/files/factsheetcampylo bacter.pdf). Accessed 3 May 2016.

29. Bless PJ, et al. A tradition and an epidemic: determinants of the campylobacteriosis winter peak in 
Switzerland. European Journal of Epidemiology 2014; 29: 527-537.

30. Suter K, Campylobacteriosis in Switzerland. Characterisation of campylobacteriosis patients. Time trend in positivity rate (MSc thesis). Basel, Switzerland: University of Basel \& Swiss Tropical and Public Health Institute; 2014, 107 pp.

31. Swiss Federal Statistical Office. Swiss Statistics Website: Medical Statistic of Hospitals [in German] (http://www. bfs.admin.ch/bfs/portal/de/index/themen/14/04/01/data/ 01/05.html). Accessed 3 April 2014.

32. TARMED. TARMED tariff version $1 \cdot 08 \cdot 0000$ of 1 June 2012 [in German] (http://www.tarmedsuisse.ch/pdf-tarif browser.html). Accessed 20 April 2016.

33. NewIndex AG. Cantonal tariff point values [in German] (http://www.newindex.ch/Taxpunktwerte-100). Accessed 20 April 2016.

34. Federal Department of Home Affairs. Official laboratory tariff list from 1 January 2012. Appendix 3 of 'Ordinance of the FDHA from 29 September 1995 on payments of the compulsory health insurance SR $832 \cdot 112 \cdot 31$ '. Bern, 2012 [in German] (http://www.bag.admin.ch/al).

35. Swiss Federal Statistical Office. List of pharmaceutical specialities as per 1 January 2012 [in German] (http:// www.sl.bag.admin.ch). Accessed 24 April 2015.

36. SwissDRG. SwissDRG version 1.0 [in German] (http:// www.swissdrg.org/de/12_archiv/swissDRG_system_1.0.asp). Accessed 6 November 2015.

37. Ministry for public health and social welfare of the canton of Bern. Overview of inpatient hospital rates 2012 from canton Bern [in German] (http://www.gef.be.ch/gef/de/ index/gesundheit/gesundheit/spitalversorgung/spitaeler/ superprovisorischetarife.assetref/dam/documents/GEF/ SPA/de/Spitalversorgung/Tarife/Tarif $\%$ C3\%BCbersicht_ 2012_d_141016.pdf). Accessed 6 November 2015.

38. van den Brandhof WE, et al. General practitioner practices in requesting laboratory tests for patients with gastroenteritis in the Netherlands, 2001-2002. BMC Family Practice 2006; 7: 56.

39. Scallan E, et al. Factors associated with seeking medical care and submitting a stool sample in estimating the burden of foodborne illness. Foodborne Pathogens and Disease 2006; 3: 432-438.
40. Hennessy TW, et al. Survey of physician diagnostic practices for patients with acute diarrhea: Clinical and public health implications. Clinical Infectious Diseases 2004; 38: S203-S211.

41. Wheeler JG, et al. Study of infectious intestinal disease in England: rates in the community, presenting to general practice, and reported to national surveillance. The Infectious Intestinal Disease Study Executive. British Medical Journal 1999; 318: 1046-1050.

42. Schweiger A, Markwalder K, Vogt M. Infectious diarrhoea: epidemiology, clinic, and diagnostics [in German]. Swiss Medical Forum 2005; 5: 714-723.

43. Federal Office of Public Health. Detailed data on salmonellosis [in German] (http://www.bag.admin.ch/k_m meldesystem/00733/00813/index.html?webgrab_path=aH R0cDovL3d3dy5iYWctYW53LmFkbWluLmNoL2lu ZnJlcG9ydGluZy9kYXRlbmRldGFpbHMvZC9zYW xtb25lbGxhLmh0bQ\%3D\%3D\&lang=de). Accessed 3 February 2015.

44. Federal Office of Public Health. Detailed data on shigellosis [in German] (http://www.bag.admin.ch/k_m_meldesys tem/00733/00813/index.html?webgrab_path=aHR0cDovL 3d3dy5iYWctYW53LmFkbWluLmNoL2luZnJlcG9ydG luZy9kYXRlbmRldGFpbHMvZC9zaGlnZWxsYS5od G0\%3D\&lang=de). Accessed 3 February 2015.

45. Gibbons CL, et al. Measuring underreporting and underascertainment in infectious disease datasets: a comparison of methods. BMC Public Health 2014; 14: 147.

46. Tam CC, et al. Longitudinal study of infectious intestinal disease in the UK (IID2 study): incidence in the community and presenting to general practice. Gut 2012; 61: 69-77.

47. Havelaar AH, et al. Immunity to Campylobacter: its role in risk assessment and epidemiology. Critical Reviews in Microbiology 2009; 35: 1-22.

48. Brinkhof MWG, et al. Influenza-attributable mortality among the elderly in Switzerland. Swiss Medical Weekly 2006; 136: 302-309.

49. Anon. Agreement on tariffs between the Swiss organisation of pharmacies (pharmaSuisse) and santésuisse - the Swiss health insurers (santésuisse) [in German]. Final version from 06.03.2009 (http://www.pharmasuisse.org/ data/Oeffentlich/de/Themen/Tarifvertrag_LOA-IV_def_ d_09-03-6.pdf). 